\title{
損傷力学モデルによる不連続性材料の動的力学特性の 評価について
}

\section{A STUDY ON THE DYNAMIC BEHAVIOURS OF DISCONTINUOUS ROCK MASS WITH DAMAGE MECHANICS THEORY}

\author{
韓 思雄*・京谷孝史**・市川康明***・川本朓万**** \\ By Sixiong HAN, Takashi KYOYA, Yasuaki ICHIKAWA and Toshikazu KAWAMOTO
}

\begin{abstract}
In nature, discontinuities in rock mass usually exist in the form of joint sets. In the paper, an analysis method for the effects of such discontinuities on the dynamic responses of rock mass is presented by imploying the conceptions of damage mechanics theory. A numerical scheme by finite element method has developed and used to treat the problem of elastic wave travelling in jointed rock mass. In addition, an elastic wave experimental program has been carried on the specimen of mortal with artificial made joints. It has showen that the dynamic responses computed by the numerical approach using the method presented are in good agreements with those obtained in the experiment, and the applicability of damage mechanics theory to the dynamic problems of rock mass has been confirmed.
\end{abstract}

Keywords : dynamics, elastic wave, discontinuity, damage tensor, FEM, amplitude, velocity, frequency

\section{1. 緒言}

近年，原子力建屋後背岩盤斜面の地震時における安定 性の問題に代表されるように，岩盤の動的力学特性を正 確に評価することの必要性が高まっている．このような 傾向は, 放射性廃棄物の地下処理, 石油や熱水の備蓄, 超伝導を利用した電力貯蔵など，高度な先進技術の基盤 としての岩盤の利用が増えるにつれてますます強くなる 亡思われる.

岩盤の動的力学特性に関する微視的な機構とその力学 的な取り扱いは最近の観察手段の進歩とともに著しく発 展してきている. 不連続性岩盤における波動の伝播特性 に関して数多くの研究がなされているが，それらの研究 は岩盤と岩盤が内包する不連続面に対する見方に基づい て大きく2つに大別できる.すなわち無数の不連続面を 含んだ岩盤をそれと等価な連続体に置き換え，波動伝播 の問題を連続体力学理論の枠内で取り扱い, 時間領域あ

* 学生会員 工修 名古屋大学大学院博士後期課程 ( \%464 名古屋市千種区不老町)

** 正会員 工修 名古屋大学助手 工学部地盤工学科 (同上)

*** 正会員 工博 名古屋大学講師 工学部土木工学科 (同上)

**** 正会員 工博 名古屋大学教授 工学部地盤工学科 (同上)
るいは周波数領域で解こうとするもの ${ }^{4), 10), 17)}$ と岩盤をそ のまま不連続体としてとらえ, 個々の不連続面を対象と して, 破壊力学理論に基づいて不連続面周辺の波動の乱 れや, それに伴う亀裂先端の動的応力拡大係数の変化な どを明らかにすることを通じて，岩盤の波動伝播特性を 評価しようとするもの ${ }^{5) .13)}$ である. また，実験的研究と しては, 精密な動的光弾性実験を行うことによって, 材 料内部の亀裂の周辺の応力波分布状態を調へ，材料内部 の波動の散乱現象を定性的に解釈することも試みられて いる12),14).

しかしながら, 無数の分布不連続面を含む岩盤に対し ては，前者の方では岩盤をどのような連続体に置き換え るべきかという点に問題が残るし，また，後者の局所的 な方法では岩盤内に複雑に分布する不連続面での波動の 反射や相互干渉性の取り扱いに問題が残る．不連続性岩 盤の総体としての動的力学特性を把握するために, 上記 の方法の中間に位置するような新しい力学的な取り扱い 方法を考える必要があると思われる.

著者らは, 不連続性岩盤の静的問題を対象として, そ の変形・破壊挙動を予測するために損傷力学の考え方を 導入していくつかの成果を挙げている(1),7),81. 損傷力学 理論においては，岩盤内部に分布する無数の不連続面を 損傷テンソルとよばれる 2 階の対称テンソルで定量する 
ことによって, 不連続性岩盤の力学挙動を連続体力学の 範囲で取り扱うものである. 本研究では，これを動的問 題に対応できるようにして無数の不連続面をもつ岩盤の 動的力学特性を取り扱う動的損傷力学モデルを提案す る.そして，規則的に不連続面を配置した供試体を用い て弾性波実験を実施し，不連続面が波動の振幅および速 度に与える力学的な影響を調べるとともに，提案した動 的損傷力学モデルでの数值解析結果と比較して, 損傷力 学理論の動的問題への適用性について検討を行うもので ある.

\section{2. 岩盤に対する動的損傷力学モデル}

動的損傷力学モデルは，すでに定式化されている静的 問題を対象とした損傷力学モデル1),61において, 運動量 保存則を加速度項までを含めて考えた場合として定式化 される.ここでは, 損傷テンソル, 実質応力, 構成則の 導入の仕方などの損傷力学モデルの基本的な考え方を概 説し, 上に述べた意味での静的損傷力学モデルの拡張と しての動的損傷力学モデルの定式化, およびその数值解 析手法について述べる。

\section{（1）岩盤の損傷テンソルと実質応力}

岩盤内に分布する不連続面群は，各不連続面が厚みを 有しない平面であるとの理想化のもとに次式で与えられ る損傷テンソルによって定量化される1．

$$
\boldsymbol{Q}=\frac{l}{V} \sum_{k=1}^{N} a^{k}\left(\boldsymbol{n}^{k} \otimes \boldsymbol{n}^{k}\right)
$$

ここに, $V$ は $N$ 個の不連続面が含まれている岩塊の体 積, $a_{k}$ は $k$ 番目の不連続面の面積, $\boldsymbol{n}$ はその単位法線 ベクトルであり, இはテンソル積を表わしている. また, $l$ は不連続面を含んだ岩盤が，不連続面の完全な進展に より無数の岩石ブロックの集合体と化す極限状態を考え たときの，その岩石ブロックの代表的長さを与えるもの で, 節理群の平均間隔を目安に決定される.この岩石ブ ロックをその系の構造最小単位とよぶ. 式（1）の損傷 テンソルは, 岩盤内部の有効面積の欠損率を三次元的に 表わしている。

分布不連続面のような構造的欠陥を有する材料に力が 作用すると，材料内部において実質部分（連続部分）が 受け持つ応力は，材料を連続体に理想化した場合に得ら れるコーシー応力とは異なったものになる。この応力を 実質応力とよぶ．村上ら ${ }^{61}$ は，金属のクリープ損傷理論

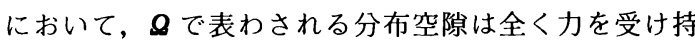

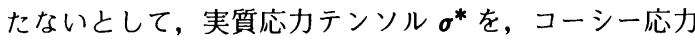
テンソル $\sigma$ と損傷テンソル $\boldsymbol{\theta}$ を用いて

$\sigma^{*}=\sigma(I-\Omega)^{-1}$

として導入している.ここに $\boldsymbol{I}$ は 2 階の恒等テンソル である，岩盤の静的変形・破壊挙動においては，岩盤内
の不連続面は応力状態に依存して不連続面に垂直な圧縮 応力や，不連続面に沿うせん断応力を一部伝達すること も考えられるので，実質応力は式 $(2)$ をもとにして

$$
\begin{aligned}
& \sigma^{*}=T^{T}\left\{\sigma_{t}^{\prime} \phi_{t}+\sigma_{n}^{\prime}\left(\boldsymbol{H}\left\langle\sigma_{n}^{\prime}\right\rangle \boldsymbol{\phi}+\boldsymbol{H}\left\langle-\sigma_{n}^{\prime}\right\rangle \phi_{n}\right)\right\} \boldsymbol{T} \cdots \cdots(3) \\
& \phi_{t}=\left(I-C_{t} \boldsymbol{Q}^{\prime}\right)^{-1}, \quad \phi=\left(I-\boldsymbol{Q}^{\prime}\right)^{-1}, \quad \phi_{n}=\left(I-C_{n} \boldsymbol{Q}^{\prime}\right)^{-1}
\end{aligned}
$$

として定義される7゙.ここに，T は損傷テンソル $\boldsymbol{Q}$ を 次式によって対角化する座標変換テンソルである.

$$
\boldsymbol{Q}^{\prime}=\boldsymbol{T} \boldsymbol{Q} \boldsymbol{T}^{T}
$$

また， $\sigma_{n}^{\prime} と \sigma_{t}^{\prime}$ は， $\boldsymbol{T}$ によって $\boldsymbol{Q}$ の主軸方向に変換さ れたコーシー応力テンソル $\sigma^{\prime}$ :

$$
\sigma^{\prime}=\boldsymbol{T} \sigma \boldsymbol{T}^{T}
$$

の対角項と非対角項への分解 :

$$
\sigma^{\prime}=\sigma_{n}^{\prime}+\sigma_{t}^{\prime}
$$

であり, 不連続面に垂直な応力と不連続面に沿うせん断 応力を表わす. $C_{n}$ と $C_{t}$ は 0 から 1 の間の値をとる係 数で, $\sigma_{n}^{\prime}$ と $\sigma_{t}^{\prime}$ の伝達性を通じて不連続面の損傷効果を 表わすものである.また， $H\langle\cdot 〉 は$

$$
H_{i j}\left\langle x_{i j}\right\rangle=\left\{\begin{array}{ll}
1 & x_{i j}>0 \\
0 & x_{i j} \leq 0
\end{array},(i, j \text { について和をとらない })\right.
$$

なる 2 階のテンソルに対するスイッチング作用素を表わ している. $C_{n}=C_{t}=1$ のとき，式（3）は式（2）と 一致する.

\section{（2）構成則の導入}

損傷力学理論では, 実質応力が損傷材料の実質部分に 働いて材料の力学挙動を支配すると考えられ，構成則は 実質応力 $\sigma^{*}$ とひずみ $\varepsilon$ を結びつける関係として導入さ れる.

岩盤における静的問題については，構成則は一般的に

$$
\sigma^{*}=\Phi(\varepsilon), \quad \varepsilon=\Phi^{-1}\left(\sigma^{*}\right) \text {. }
$$

の形で与えられ, 構造最小単位よりも小さな岩石供試体 の試験を行えば，供試体においては $\boldsymbol{Q}=\mathbf{0}$, したがって $\sigma^{*}=\sigma$ となるので，供試体が示す応力ひずみ関係その ものとして決定される71,9).

式（6）は, 岩盤の静的変形・破壊挙動における不連 続面の損傷効果が, 有効断面の欠損を通じての見掛けの コーシー応力の効果を強調することにあるということを 具現したものである. 一方，岩盤における波動の伝播と いうような動的問題においては, 岩盤内の分布不連続面 が有する力学的な効果としては, 式（6）に表わされる 見掛けの応力に対する強調効果だけでなく，不連続面の 配置による波動の反射，散乱，および減衰なども考慮せ ねばならない，不連続面の波動伝播に対するこのような 効果は不連続面の空間的配置そのものが支配要因であ り，静的な変形・破壊挙動に対する応力の強調効果とは 少し違った意味合いをもっている.したがって，このよ うな効果を構成則中に表現すべきかどうかは検討の余地 があるところであるが，波動に対する不連続面の減衰効 
果を考慮する 1 つの方法として, 構成則を次のような形 で考えることも可能であろう.

$$
\sigma^{*}=\Phi(\varepsilon)+\boldsymbol{\Psi}(\boldsymbol{Q}, \dot{\varepsilon})
$$

式（7）は岩盤基質部を弾性体と仮定した場合には，D を弾性マトリックス, $\boldsymbol{C}$ を減哀マトリックスとして

$$
\sigma^{*}=D \varepsilon+C \dot{\varepsilon}, \quad C=C(\boldsymbol{Q})
$$

と書かれる.ここに, $\dot{\varepsilon}$ はひずみ速度を表わしている. 式 (7) あるいは式 (8) の構成則の右辺第 2 項は不連 続面の配置による減衰効果を表わす項である.ただし， この項をどのようにして実験などから定めるかは今後の 研究課題である.

\section{（３）不連続性岩盤における運動方程式}

岩盤内部の不連続面は運動の過程においても平面で, しかもその厚みは無視できると仮定すれば，岩盤に対す る質量保存則は連続体に対するそれと同じものとなる.

また，静的変形に対する損傷理論 ${ }^{7), 22)}$ と同様に，損傷 材料に対して運動方程式を成立せしめる可容応力として コーシー応力を考えると，結局運動方程式は連続体と同 じ形

$$
\rho \ddot{u}=\nabla \cdot \boldsymbol{\sigma}+\boldsymbol{f}
$$

となる．ここに, $\rho$ は岩盤の密度, $\ddot{u}$ は変位加速度, $\boldsymbol{f}$ は体積力ベクトルを表わす. 式 (9) 中のコーシー応力 $\sigma$ を式 (3) によって実質応力 $\boldsymbol{\sigma}^{*}$ に書き換えて整理す ると

$$
\rho \ddot{u}=\nabla \cdot\left(\sigma^{*}-\boldsymbol{\phi}\right)+\boldsymbol{f}
$$

を得る。ここに $中$ は

$$
\boldsymbol{\psi}=\boldsymbol{T}^{T}\left\{\sigma_{t}^{\prime}\left(\phi_{t}-\boldsymbol{I}\right)+\sigma_{n}^{\prime}\left(\boldsymbol{H}\left\langle\sigma_{n}^{\prime}\right\rangle \phi+\boldsymbol{H}\left\langle-\sigma_{n}^{\prime}\right\rangle \phi_{n}-I\right)\right\} \boldsymbol{T}
$$

で与えられるテンソルで, 式 (3) 中の係数が $C_{t}=C_{n}$ =1のときは

$$
\boldsymbol{\psi}=\sigma(I-Q)^{-1} \boldsymbol{Q}=\sigma^{*} \boldsymbol{Q}
$$

となる。

式（10）がどのような解を与えるかということを説明 するために,完全に開口したクラックが空間内で一様に， その方向においてランダムに分布していて，損傷テンソ ルがいたるところで $\boldsymbol{Q}=\boldsymbol{\Omega I}$ で与えられるような等方損 傷”を受けた等方弾性体中の一次元波動伝播を考える. 減衰がないとして構成則は式（8）より，Lameの定数 $\mu, \lambda$ を用いて

$$
\boldsymbol{\sigma}^{*}=2 \mu \varepsilon+\lambda(\operatorname{tr} \varepsilon) \boldsymbol{I}
$$

で与えられ, さらにクラックは開口なので, $C_{t}=C_{n}=1$ として式（3）より

$$
\sigma^{*}=\frac{1}{1-\Omega} \sigma=2 \mu \varepsilon+\lambda(\operatorname{tr} \varepsilon) \boldsymbol{I}
$$

となる．これを，式（12）とともに式（10）に代入して, ひずみを変位 $\boldsymbol{u}$ に書き換えると

$$
\rho \frac{\partial^{2}}{\partial t^{2}} \boldsymbol{u}=(1-\Omega) \mu \nabla^{2} \boldsymbol{u}+(1-\Omega)(\lambda+\mu) \nabla(\nabla \cdot \boldsymbol{u})+\boldsymbol{f}
$$

を得る.したがって, 平面弾性波の伝播速度は

$$
\begin{aligned}
& V_{P}^{*}=\sqrt{(1-\Omega) \frac{\lambda+2 \mu}{\rho}}=\sqrt{1-\Omega} V_{P} \\
& V_{S}^{*}=\sqrt{(1-\Omega) \frac{\mu}{\rho}}=\sqrt{1-\Omega} V_{s}
\end{aligned}
$$

となり，損傷がない場合に比べて $\sqrt{(1-\Omega)}$ 倍だけ遅く なることがわかる。

\section{(4) 有限要素離散化}

運動方程式（10）の弱形式は許容変位 $\boldsymbol{\delta} \boldsymbol{u}$ を用いて

$\int_{v} \rho \ddot{u} \cdot \delta u d V=\int_{v}\left\{\nabla \cdot\left(\sigma^{*}-\boldsymbol{\psi}\right)+\boldsymbol{f}\right\} \cdot \delta u d V$

と書け, 発散定理およびコーシーの公式 $\boldsymbol{t}^{0}=\boldsymbol{o n}$ を用い $\tau$

$$
\begin{gathered}
\int_{V} \rho \ddot{u} \cdot \delta u d V+\int_{V} \sigma^{*} \cdot \delta \varepsilon d V=\int_{s_{t}} t^{0} \cdot \delta u d V+\int_{V} f \cdot \delta u d V \\
\quad+\int_{V} \phi \cdot \delta \varepsilon d V \ldots \ldots \ldots \ldots \ldots \ldots \ldots \ldots \ldots \ldots \ldots \ldots \ldots \ldots \ldots \ldots \ldots \ldots \ldots \ldots \ldots \ldots \ldots \ldots \ldots
\end{gathered}
$$

を得る.ここに $\boldsymbol{t}^{0}$ は境界 $S_{t}$ 上に与えられた表面荷重べ クトルである.

構成則が式（８）で与えられる場合, 式（18）の有限 要素法による離散化を施すことによって次のような連立 微分方程式を得る.

$$
[M]\{\ddot{U}\}+[C]\{\dot{U}\}+[K]\{U\}=\{F\}+\left\{F^{*}\right\} .
$$

ここに, $\{U\}$ は節点変位, $\{\bullet\}$ はその時間微分を表わす. また, $[M],[C],[K]$ はそれぞれ質量マトリックス, 减 衰マトリックス, 剛性マトリックスであり, $[N]$ を形状 関数マトリックス, $[B]$ を節点変位ひずみ関係マトリッ クスとして

$$
\begin{gathered}
{[M]=\int_{V} \rho[N]^{T}[N] d V} \\
{[C]=\int_{V}[B]^{T}[C][B] d V} \\
{[K]=\int_{V}[B]^{T}[D][B] d V}
\end{gathered}
$$

で与えられる. $\{F\}$ は節点荷重ベクトル, $\left\{F^{*} \mid\right.$ は不連続 面の損傷効果を表わす付加的な荷重ベクトルで

$$
\left.\begin{array}{l}
\{F\}=\int_{s_{t}}[N]^{T}\left\{t^{0}\right\} d s+\int_{V}[N]^{T}\{f\} d V \\
\left\{F^{*}\right\}=\int_{V}[B]^{T}\{\phi\} d V
\end{array}\right\}
$$

で与えられる.

\section{3. 不連続面を配置した供試体の弾性波実験と 数值解析}

規則的に不連続面を配置した石高供試体に対して弾性 波（P波）試験を実施し, 不連続面群の角度による伝播 特性の違いを調べた。 そして, 提案モデルによる数値解 
析を行って実験値と比較し, 提案モデルの妥当性を検討 した.

\section{（1）弾性波実験}

石高（医薬用）と標準砂および水を重量比にして 1 対 2 対 3 で混合し, Fig.1(a) に示すような厚さ $6 \mathrm{~cm}$ の 正十六角形の供試体を作成した。この石高試料の材料特 性を Table 1 に示す. 弾性係数は動的弾性係数であり, ポアソン比は静的なものと同じと仮定している. 試料を 型枠に流し込んだ後, 完全に固まらないうちに幅 $3 \mathrm{~cm}$ のボール紙を用いて 24 本の完全に開口した不連続面を 形成した (Fig.1(b)). 供試体は打設後 90 分で型枠か らはずし, その後恒温室 $\left(22 \pm 1^{\circ}\right)$ で 7 日間養生した後 に実験に供した。

Fig. 2 に示す測定系により供試体の向かい合う 8 方向 の面に加速度型弾性波発振子と受振子をあてて伝播する 弾性波を測定した. 振動子と供試体の試面との接触面に おける波の損失を減らすために, 瞬間接着剤を用いて振 動子を完全に試料面に接着した，発振子から出力する加 速度波は $50 \mathrm{kHz}$ のパルス波である. 発振子を受振子に 直接当てて測定した入力加速度の波形およびそのフーリ エスペクトルを Fig. 3 に示す.

\section{(2) 数值解析}

解析に用いた有限要素分割図を境界条件とともに Fig. 4 に示す. 解析モデルでは受振側に粘性境界を置い ている. Table 1 にみる材料定数より, 供試体に不連続 面が存在しない場合には供試体内を伝播する加速度波の 波長はおよそ $3 \mathrm{~cm}$ になることがわかるので, 要素分割 は $3 \mathrm{~cm}$ 中に 8 つの要素が入るように行っており, 要素 数は 5220 個である.

解析では基質部を等方均質弾性体として扱い Table 1 に示した材料定数を用いる. Fig.1(a) に示す 24 本の亀 裂を含んでいる材料に対して, 体積 $V$ が $3227 \mathrm{~cm}^{3}$, 亀 裂面積 $a^{k}$ が $18 \mathrm{~cm}^{2}$, 亀裂間隙により最小単位の寸法 $l$ が $3 \mathrm{~cm}$ と定められ, 波動の入射方向と不連続面の法線 との間の角度 $\theta$ が $\theta=0^{\circ}, 22.5^{\circ}, 45^{\circ}, 67.5^{\circ}$ ，および $90^{\circ}$

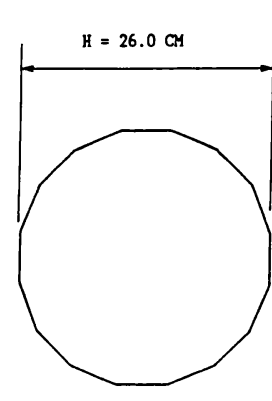

(a) Shape of specimen (b) Distribution of cracks

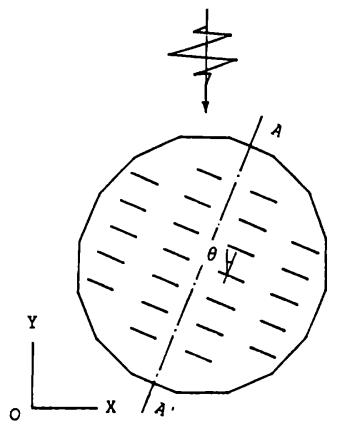

Fig. 1 Specimen for experiment.
のときの損傷テンソルが，それぞれ次のように求められ る.

$$
\begin{aligned}
& \boldsymbol{\Omega}^{\left(0^{\circ}\right)}=\left(\begin{array}{ll}
0.000 & 0.000 \\
0.000 & 0.402
\end{array}\right), \quad \boldsymbol{Q}^{\left(22.5^{\circ}\right)}=\left(\begin{array}{ll}
0.059 & 0.142 \\
0.142 & 0.343
\end{array}\right) \\
& \boldsymbol{\Omega}^{\left(45^{\circ}\right)}=\left(\begin{array}{ll}
0.201 & 0.201 \\
0.201 & 0.201
\end{array}\right), \quad \boldsymbol{Q}^{\left(67.5^{\circ}\right)}=\left(\begin{array}{cc}
0.343 & 0.142 \\
0.142 & 0.059
\end{array}\right)
\end{aligned}
$$

Table 1 Meterial Constants.

\begin{tabular}{|l|c|}
\hline Young's Modulus E (MPa) & $2.40 \times 10^{3}$ \\
\hline Poisson's Ratio $\nu$ & 0.1 \\
\hline Unit Neight $\gamma\left(\mathrm{gf} / \mathrm{cm}^{3}\right)$ & 1.17 \\
\hline Crack Numbers & 24 \\
\hline Crack Length $\quad(\mathrm{cm})$ & 3 \\
\hline
\end{tabular}

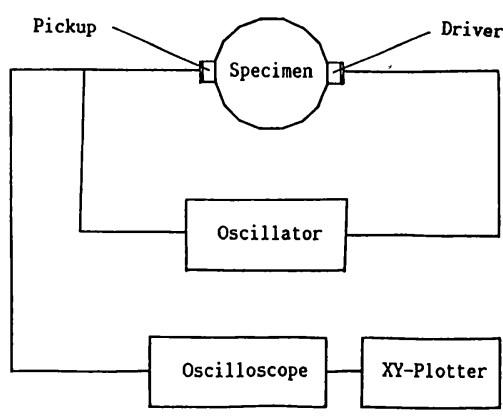

Fig. 2 Layout of test system.

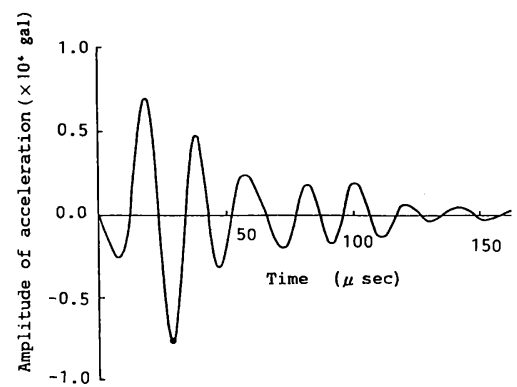

Fig. 3(a) Input acceleration wave.

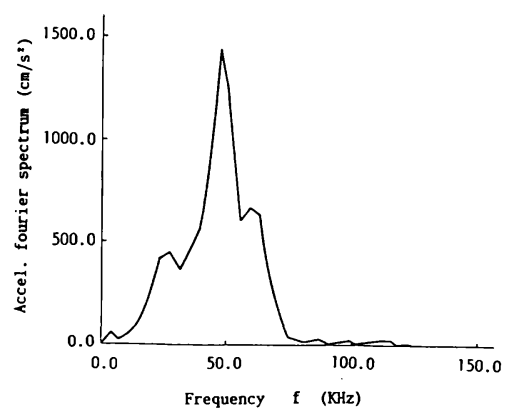

Fig. 3(b) Fourier spectrum of input wave. 


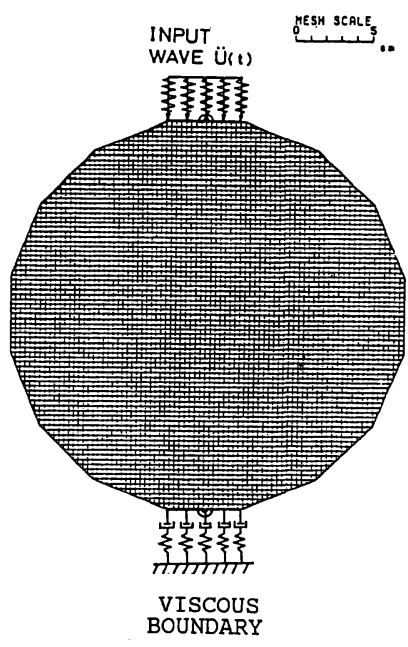

Fig. 4 Mesh for FEM analysis.

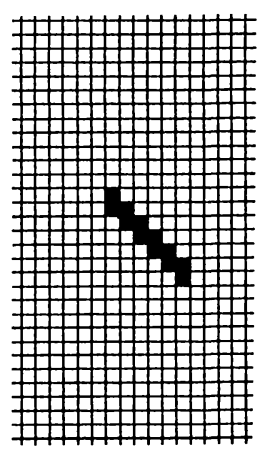

Fig. 5 Cracked model.

$$
\boldsymbol{\Omega}^{\left(90^{\circ}\right)}=\left(\begin{array}{ll}
0.402 & 0.000 \\
0.000 & 0.000
\end{array}\right)
$$

不連続面は開口なので, 実質応力の定義式 ( 3 ) 中の $C_{t}=C_{n}$ はともに 1.0 とする.

運動方程式 (19) の解法には陽的中心差分法を用いる. すなわち, 質量マトリックス $[M]$ と減衰マトリックス $[C]$ は式 $(20)$ によらず, $[\boldsymbol{M}]$ を集中質量マトリックス (Lamped Mass Matrix) とし, さらに [C]は Rayleigh 减衰 $[C]=\alpha[M]+\beta[K]$ において $\beta=0$ とした 形で与えることとし, 入力波に対する受振波の最大振幅 の比率が最もよく実験に合うように定めることとする. 式（19）の中心差分式を示すと以下のようである.

$$
\begin{aligned}
& \left(\frac{[M]}{\Delta t^{2}}+\frac{[C]}{2 \Delta t}\right)\left\{U_{n+1}\right\}=\left\{F_{n}\right\}+\left\{F_{n}^{*}\right\} \\
& \quad-\left([K]-\frac{2}{\Delta t}[M]\right)\left\{U_{n}\right\}-\left(\frac{[M]}{\Delta t^{2}}-\frac{[C]}{2 \Delta t}\right)\left\{U_{n-1}\right\}
\end{aligned}
$$

式 (23) 右辺はすべて既知項である. 特に $\left\{F^{*}\right\}$ は式 (12)，(21）より次式で与えられる.

$$
\left\{F_{n}^{*}\right\}=\int_{V}[B]^{T}\left(\left\{\sigma^{*}\right\}\{\Omega\}\right) d V=\int_{V}[B]^{T}\left([D]\left\{U_{n}\right\}\{\Omega\}\right) d V
$$

時間間隔 $\Delta t$ は亀裂が全くない場合において安定な解を 与える $\Delta t=0.5 \mu \mathrm{s}$ とした.

また比較のために, Fig. 5 に示すように, 亀裂に対応 する部分の要素のヤング係数を $E=1.0 \times 10^{-4} \mathrm{MPa}$ に 低下させることによって龟裂を陽的に表現した有限要素 モデルを用いての数值解析も行った.

\section{（3）実験および数值解析の結果と考察}

a) 周波数特性

Fig.6( i )〜（iii）それぞれに, 実験, 損傷解析および クラックモデルによる解析によって得られた受振点での 加速度波形とそのフーリエスペクトルを示す．ただし， 損傷解析は, $[C]$ において $\alpha=8000$ とした場合の結果 である。

Fig. 6( i ) の実験結果をみると, 波動の入射方向と亀 裂面が平行の場合 (Fig.6(i ) (c), $\theta=90^{\circ}$ ), スペクト ルの形はFig. 3(b) にみる入力波のスペクトルと全く同 じ形をしているが, 亀裂面の角度が入射方向に対して垂 直に近くなるにつれて, $50 \mathrm{kHz}$ 付近のピーク值は低下 し, $50 \mathrm{kHz}$ より低い周波数のスペクトルが大きくなっ ている様子がわかる. さらに細かくみれば，入力波のス ペクトル (Fig.3(b)) と比ベてスペクトル值は全体的 に小さくなっているが, $10 \mathrm{kHz}$ 付近の波については, $\theta$ $=45^{\circ}$ (Fig. 6(a)) の場合に増幅されているのがわかる. これは, 亀裂群における波の反射・散乱の結果であると 解釈される.

同様の傾向はFig. 6(iii) に示す不連続面を陽に表現 したクラックモデルによる解析結果でもみることができ る. ただし, この場合は, 有限要素の弾性係数を低下さ せることで表現した亀裂面での波動の反射の様子が実際 とは若干異なるために, $\theta=67.5^{\circ}$ と $\theta=45^{\circ}$ の場合に実 験結果においてみられたようなスペクトルの 2 つのピー クが周波数の高い方へずれた形で現われている.

Fig.6( ii ) の損傷モデルによる解析は, 対象を連続体 的に取り扱うという手法の性質上, 亀裂面における反 射・散乱によると思われる $10 \mathrm{kHz}$ 付近の波の増幅につ いては表現できていないが, クラックモデルの解析結果 にみられるような $50 \mathrm{kHz}$ よりも高い周波数の波の増幅 というような事実とは異なった結果を与えることもな く, 全体としては実験結果の周波数応答を比較的よく表 現しているようである.

b）最大振幅の減衰

不連続面を数多く含む媒体中を波動が伝播するとき， その波動の振幅は伝播距離に対して指数的に減衰するこ とが知られている ${ }^{16)}$. すなわち, 波の伝播方向にある基 

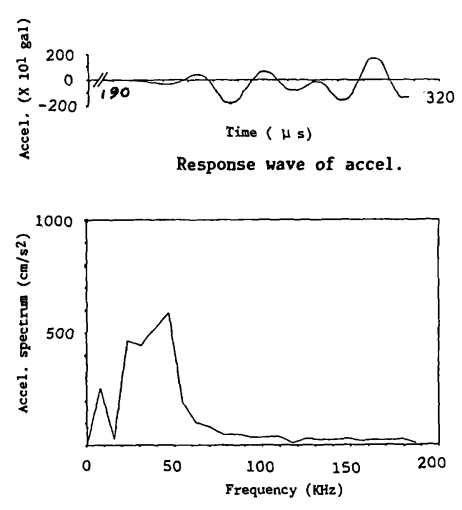

Fourier spectrum of accel.

(a) $\theta=45^{\circ}$
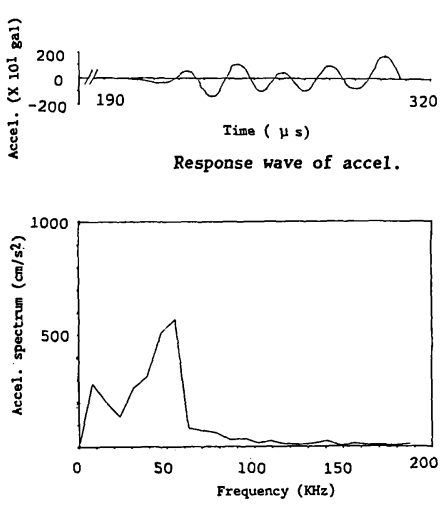

Fourier spectrum of accel.

(b) $\theta=67.5^{\circ}$

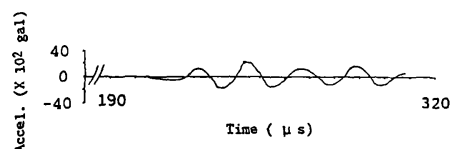

Response wave of accel.

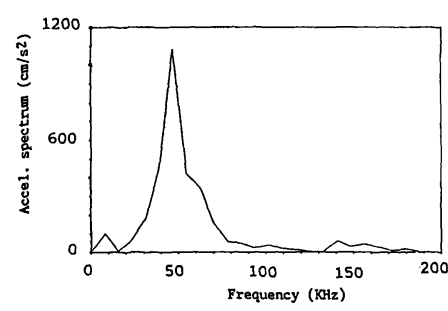

Fourier spectrun of accel.

(c) $\theta=90^{\circ}$

Fig. 6( i ) Measured acceleration responses in experiments.
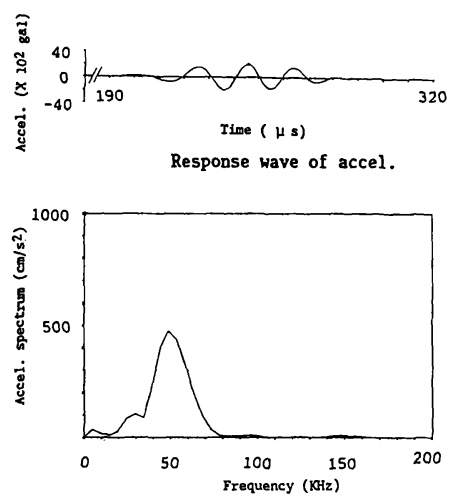

Fourier spectrum of accel.

(a) $\theta=45^{\circ}$

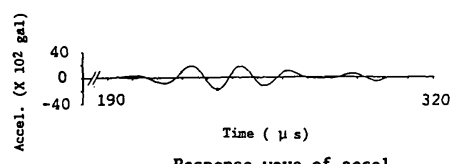

Response wave of accel.

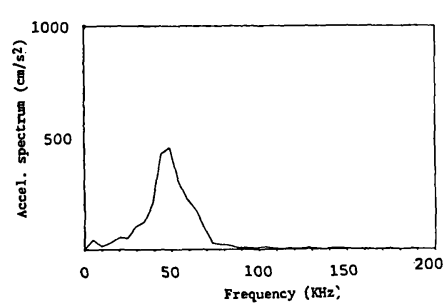

Fourier spectrum of accel.

(b) $\theta=67.5^{\circ}$

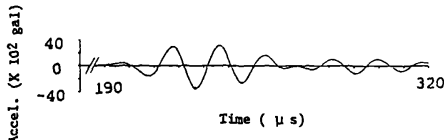

Response wave of accel.

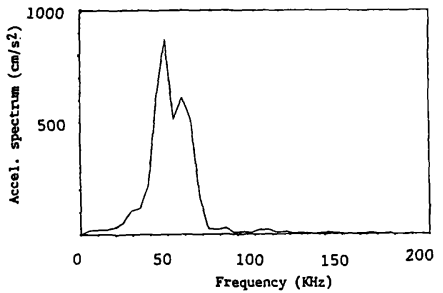

Fourier spectrum of accel.

(c) $\theta=90^{\circ}$

Fig. 6( ii ) Computed acceleration responses by damage analysis.
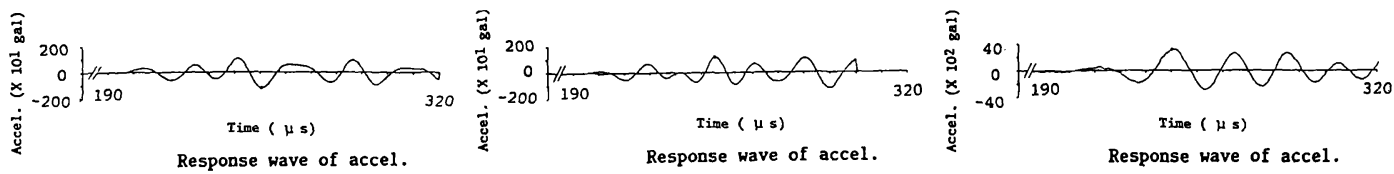

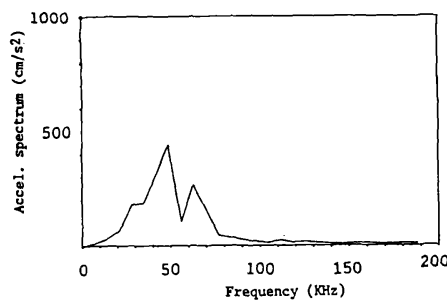

Fourier spectrum of accel.

(a) $\theta=45^{\circ}$

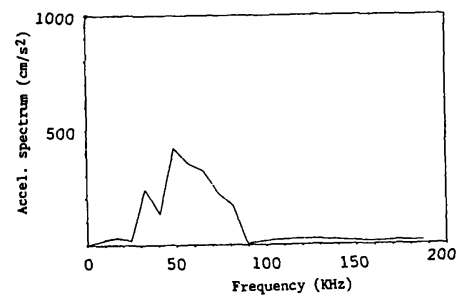

Fourier spectrum of accel.

(b) $\theta=67.5^{\circ}$

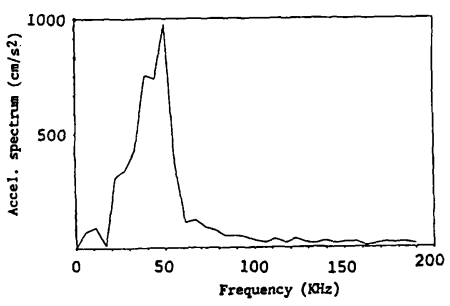

Fourier spectirum of accel.

(c) $\theta=90^{\circ}$

Fig. 6(iii) Computed acceleration responses by crack model. 


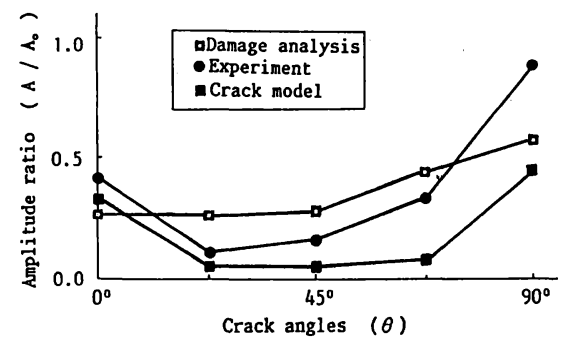

Fig. 7 The relation between the crack angles and amplitude ratio.

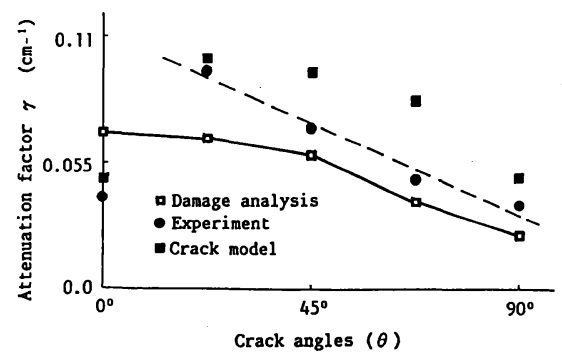

Fig. 8 The value of attenuation factor at different crack angles.

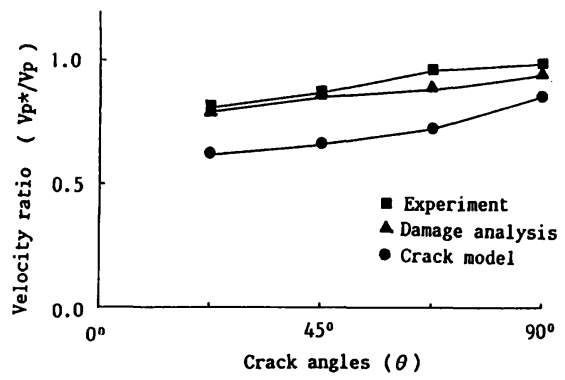

Fig. 9 The comparison of computed results with experiments.

準点を選んで,この基準点における波の振幅を $A_{0}$ とす れば, 基準点から $x$ だけ離れた点の振幅 $A$ が

$$
A=A_{0} \exp (-\gamma x) \text {. }
$$

と表現される.ここに， $\gamma$ は媒体基質部の材料と不連続 面の状態に依存した減衰定数である.

Fig.7に，実験および解析によって得られた入力波に おける最大振幅 $A_{0}$ と受振点において得られた最大振幅 $A$ との比を示す. 亀裂群の角度の違いによる最大振幅 比の変化の様子は, クラックモデルがその傾向において 実験值とよく似た変化を示しているが, 全体的において STRESS SCRLE
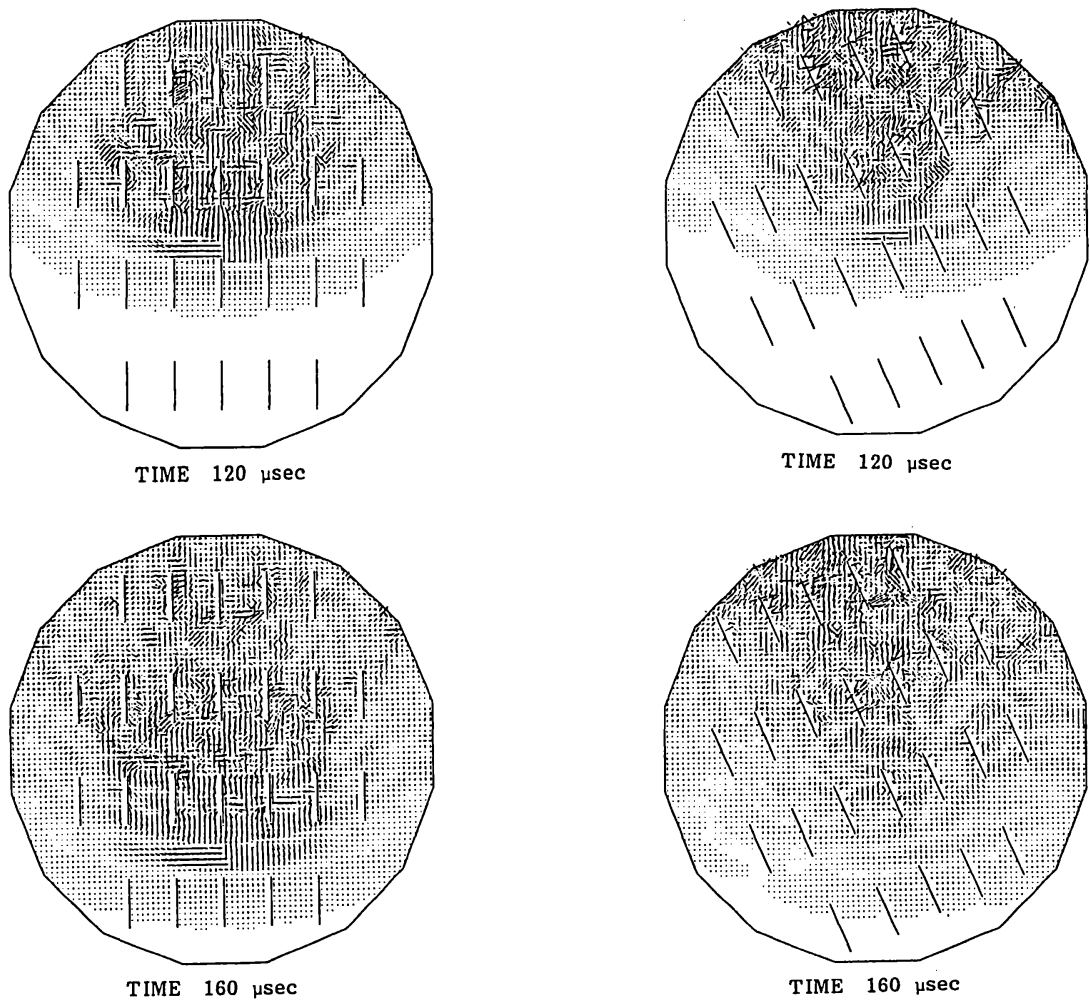

(a) $\theta=90^{\circ}$

(b) $\theta=67.5^{\circ}$ 

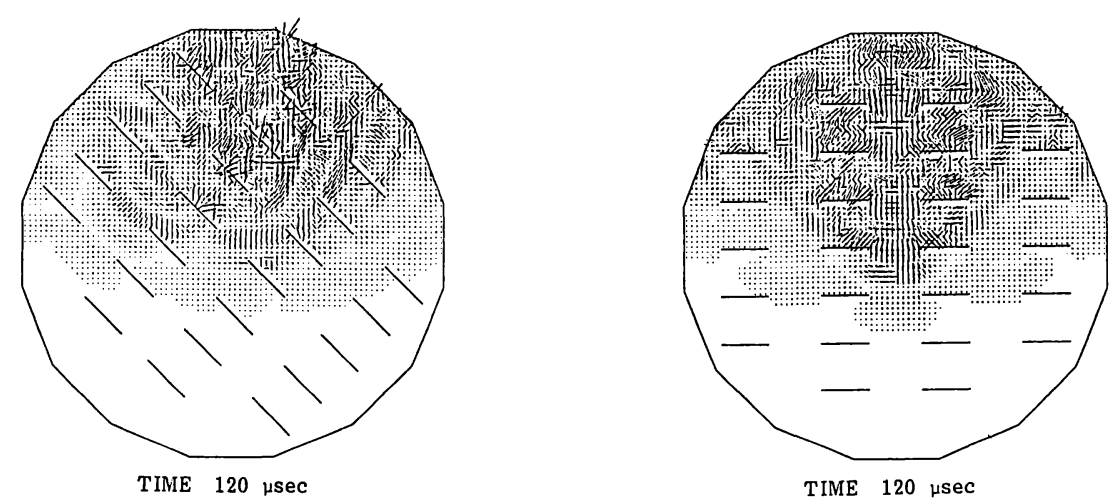

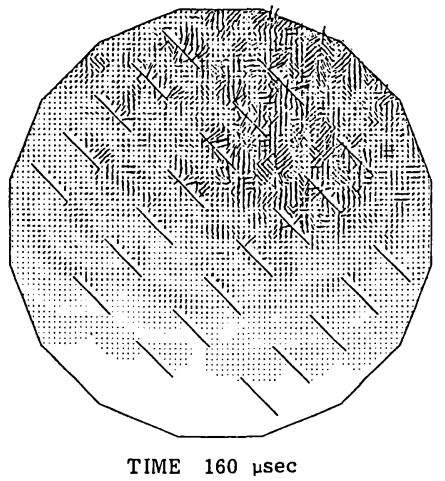

(c) $\theta=45^{\circ}$

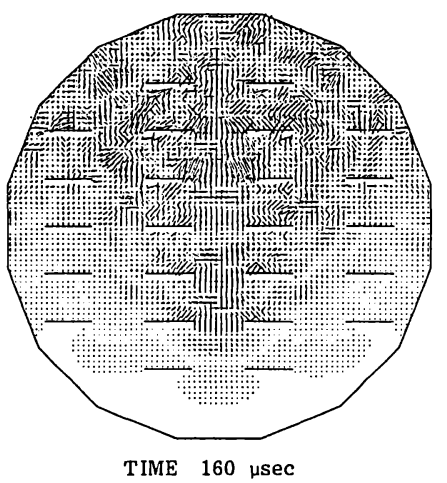

(d) $\theta=0^{\circ}$

Fig. 10 The propagation of stress wave in samples with cracks.

は損傷モデルが実験值を比較的よく押さえているといえ る.このことは, 損傷モデルにおいて, 合理的な方法で 減衰マトリックス $[C]$ を見出すことができれば，亀裂の 配置による波動の減衰についても損傷モデルは妥当な予 測を与え得ることを示唆するものである，なお，亀裂群 と入射方向が垂直となる $\theta=0^{\circ}$ の場合に, 振幅比が大き くなっているのは, Fig.1(b) にみるように, 発振子と 受振子が直線 $A-A^{\prime}$ 上に位置して, 亀裂面で反射しない 波動が卓越しているためである. 式 (24) 中の減衰係数 $\gamma$ は, 本実験においては, 発振子と受振子の距離が供試 体寸法から $x=H=26.0 \mathrm{~cm}$ なので, Fig.7に示した振 幅比 $A / A_{0}$ を用いて

$$
\gamma=-\frac{1}{H} \ln \left(A / A_{0}\right), \quad H=26.0 \mathrm{~cm}
$$

となる.この值を Fig. 7 に示した $A / A_{0}$ から計算して整 理すると Fig. 8 のようになる. 図から減衰係数亡亀裂群 の配置方向の間に近似的に線形的な関係が成り立ってい ることがわかった。この線形相関性は, 材料の亀裂の密 度が大きいほど一層強くなる傾向がみられた。

c）伝播速度の低下

Fig. 9 に実験および解析から求めた波動の伝播速度に
ついての結果を示す．伝播速度は発振ノイズと受振波形 の立ち上がりとの時間差から求められたものである. $V_{p}^{*}$ は不連続を含んだ供試体を伝わる場合の伝播速度で ある. 伝播速度比 $V_{p}^{*} / V_{p}$ は $\theta$ が小さくなるにつれて低 下していくことが示されている．損傷モデルによる解析 結果は, 実験値と非常によく一致している.

Fig. 9 と Fig. 7 を比較すると, 不連続材料を伝わる P 波が亀裂群の配置角度の変化に対して伝播速度の変化よ りも, 振幅の減衰の方がより敏感であることがわかる.

d）クラックモデルによる応力波伝播の様子

Fig.10にクラックモデルにおける応力波が時間ス テップごとに不連続体内部を伝播する様子を示す．先に 述べたように，実際とは少し異なっているとは思われる が，不連続面における波動の反射・散乱を知る手がかり にはなろう. 図をみると，亀裂の付近で波は一部分反射 され，一部分は亀裂を回折して伝播している様子がわか る. 入射方向と亀裂面との角度が垂直に近くなるほよ゙, 材料内部での波の散乱が目立ち, 反射された波の量が多 くなる様子がうかがえる.

また，亀裂によって反射された波が亀裂周辺に散乱域 (Scattering $)^{18)}$ を形成することも, 図から観察できる. 
Fig. 10(a) に示すように, $\theta=0^{\circ}$ の場合には, 波が発 振点から受振点まで, 全く不連続面の影響を受けないで 到達する波が存在しており, 本実験において $\theta=0^{\circ}$ の場 合に特異な結果が得られた理由をみることができる.

\section{4. 結言}

本研究では, 不連続性岩盤の動的力学特性を評価する ための一手法として, 損傷の概念を導入した動的損傷力 学モデルおよびその数值解析手法の提案を行った. そし て, 不連続面を配置した供試体の弾性波実験を実施し, 提案モデルによる数値解析と比較して提案手法の妥当性 を検討した，その結果，次のような知見を得た。

（1）不連続面群を含む媒体中を伝播する波動の伝播 速度は, 不連続面群と伝播方向の成す角度が垂直に近く なるほど遅くなる。

（2）不連続面による反射の繰り返しにより，高周波 数の波ほど大きく減衰される.

（３）不連続性媒体中を伝わる波動においては，振幅 の減衰の方が伝播速度よりも敏感に不連続面の影響を受 けることがわかった. また, 最大振幅の減衰を伝播距離 に関する指数則で表現した場合に，その距離減衰係数は 亀裂群の方向に線形的に依存する様子がみられた。

（4）動的損傷モデルは，不連続面の配置による伝播 速度の变化を非常によい精度で予測し得ることが確かめ られた。

（5）動的損傷モデルは，減哀マトリックス [C]を合 理的に定めることができれば，不連続面の配置による波 動の減衰特性, 周波数応答特性をよく予測し得ることが 確かめられた。

本研究で提案した動的損傷力学モデルが, 実際の岩盤 の動的力学特性評価の有力な手段となるためには, 解決 されねばならない問題点がいくつかある，そのまず第一 としては, 不連続面の配置による波動の減衰特性をどの ように定量化するかということである. 本研究で示した 解析結果と実験值のよい一致は, “減衰マトリックス $[C]$ を合理的に定めることができれば”という前提に 立っている. 不連続面の配置状態と波動の減衰特性との 関係を把握するには, 不連続面の大きさと波長の関係な ど本研究では取り扱わなかった重要な因子も数多くあ り, 今後の理論的, 実験的研究の蓄積を必要とする.

最後に本報告をまとめるにあたり，ご協力をいただい た本研究室の皆様に心から感謝いたします．また，この 研究の数值計算の一部は当時大学院生であった中原博隆 君（現・鹿島建設）とともに実施したものであることを 付記し, 感謝する.

\section{参 考 文 献}

1）京谷孝史・市川康明・川本朓万：岩盤の力学特性評価に おける損傷テンソルの適用について, 土木学会論文報告 集, 第 358 号, pp. $27 \sim 35,1985$.

2) 川本朓万・林 正夫 : 地盤工学における有限要素解析, 培風館, 1978 .

3）市川康明：増分弾塑性理論と岩質材料の破壊過程に関す る基礎的研究, 名古屋大学学位論文, 1986.

4) O'Connell, R. J. : Seismic Velocities in Dry and Saturated Crack Solids, J. of Geophys. Res., Vol.19, No. 35, pp. 5412 5426, 1974.

5) Sih, G. C. : Some Elastodynamic Problems of Cracks, Int. J. of Fracture Mech., pp. 51 69, 1968.

6) Murakami, S. and Ohno, N. : A Continuum Theory of Creep and Creep Damage, Proc. 3rd IUTAM Symp. on Creep in Structures. ed. A.R.S. Ponter and D. R. Hayhurst. Berlin, Springer-Verlag, pp. 422 443, 1980.

7) Kyoya, T., Ichikawa, Y. and Kawamoto, T. : A Damage Mechanics Theory for Discontinuous Rock Mass, Proc. Int. Conf. Numerical Method in Geomechanics, Vol. 1, Balkema, pp. 469 481, 1985.

8) Han, S., Kyoya, T., Ichikawa, Y. and Kawamoto, T. : A Dynamic Analysis of Jointed Rock Mass, Proc. Int. Symp. on Eng. in Complex Rock Formation, pp. 338 344,1986

9) Kawamoto, T., Ichikawa, Y. and Kyoya, T. : Rock Mass Discontinuities and Damage Mechanics, Proc. of Int. Conf. on Computational Mech., Vol.2, SpringerVerlag, pp. IX27 $\sim \mathrm{XX} 36$.

10) Anderson, D. L., Minster, B. and Cole, D. : The Effect of Oriented Cracked on Seismic Velocities, J. of Geophys. Res., Vol.79, No. 26, pp. 4011 4015, 1974.

11) Oda, T. : Elastic Compliance for Rock-Like Materials with Random Cracks, Soils and Foundations, Vol.24, No. 3, pp. 27 40, 1984.

12) Rossmanth, H. : Elastic Wave Interaction with a Crack Qurater-Plane, Meccanica, Vol.20, pp. 127 135, 1985.

13) Roy, A. : Diffraction of Elastic Wave by an Elliptic Crack, Int. J. Engng. Sci., Vol.22, No.6, pp.729 $739,1984$.

14) Dally, J.W. : Photoelastic Studies of Stress Wave Propagation, Modern Problems in Elastic Wave Propagation, John Wiley \& Sons, pp.3 21, 1978.

15）金子勝比古・井上博之・佐々宏一・伊藤一郎：岩石の破 壊の進展に伴う弾性波伝播速度の変化, 日本鉱業誌, Vol. 94, No. 1080, pp. 77 83, 1978.

16) Kolsky, H. : Stress Wave in Solid, Oxford Univ. Press, London, 1953.

17) Walsh, J. B. : Attenuation in Partially Melted Material, J. of Geophys. Res., Vol.73, No. 35, pp. 2209 2216, 1968.

18) Waterman, P.C. : Multiple Scattering of Waves, J. of Maths. Phys., Vol.2, pp. 512 537, 1961.

19）柳谷 俊・寺田 孚: 弾性波 CTによる岩石のダイレイ タンシー局所化の観察, 土木学会論文集, 第 370 号, 
pp. 159 168, 1986.

20) Lysmer, J. and Kulemeyer, R. L. : Finite Dynamic Model for Infinite Media, J. of the Eng. Mech. Division, pp. 859 877, 1967.

21) Thomason, W. T., et al. : A Numerical Study of Damping, Earth. Eng. \& Struct. Dyn., Vol. 3, pp. 97 103, 1974.
22) Kawamoto, T., Ichikawa, Y. and Kyoya, T. : Deformation and Fracturing Behaviour of Discontinuous Rock Mass and Damage Mechanics Theory, Int. J. for Num. and Analytical Method in Geomech., Vol.12, pp. $1 \sim 30,1988$.

(1987.12.1 - 受付) 